\title{
Chemical compositions, antimicrobial effects, and cytotoxicity of Asia minor wormwood (Artemisia splendens Willd.) growing in Iran
}

\author{
Fariba Heshmati Afshar ${ }^{1}$, Masumeh Zadehkamand ${ }^{2,3}$, Zahra Rezaei ${ }^{3}$, Abbas Delazar ${ }^{4,5}$, Vahideh Tarhriz ${ }^{6}$ and \\ Parina Asgharian ${ }^{4,5^{*}}$
}

\begin{abstract}
Background: Artemisia splendens from the Asteraceae family is a new source of biologically active compounds. The current study investigated to evaluate antimicrobial and cytotoxicity activity of methanolic extracts and their fractions obtained from aerial parts by agar disk diffusion and MTT methods, respectively. The active fractions were subjected to preparative HPLC for isolating the pure compounds, which were structurally elucidated, by ${ }^{1} \mathrm{H}$ and ${ }^{13} \mathrm{C} \mathrm{NMR}$.

Results: The results showed that the methanolic extract and its 60\% SPE fraction have the anti-proliferative activity on A549 cell line in comparison with the control group. Meanwhile, the methanolic extract and its 40\% SPE fraction can inhibit the growth of Gram-positive strains as anti-microbial activity. The 60\% SPE fraction also illustrated anti-proliferative activity on the HT-29 cell line compared to the control group. Chromatographic separations via preparative HPLC yielded 5 flavonoids and three flavonoid glycosides.
\end{abstract}

Conclusion: Based on the results it can be concluded that A. splendens as a potential source of cytotoxic and antimicrobial compounds can be used in pharmaceutics.

Keywords: Artemisia splendens, Anti-proliferative activity, Antimicrobial activity, Cancerous cell lines, Flavonoids

\section{Introduction}

The genus Artemisia is one of the largest and most important genera of the Asteraceae family used in traditional medicine worldwide [1]. Biologically active secondary metabolites such as phenolic compounds (flavonoids, phenylpropanoids, and coumarins), and terpenoids (sesquiterpene lactones) [2], which were isolated from plants of this genus, exhibited various pharmacological activities such as antimalarial, antitumor, antioxidant [3], anti-microbial [4], and anti-inflammatory [5]. It is also a

*Correspondence: parina.asgharian@gmail.com

${ }^{4}$ Drug Applied Research Center, Tabriz University of Medical Sciences, Tabriz, Iran

Full list of author information is available at the end of the article large genus (with about 400 species), distributed in different parts of the world particularly in Europe, North America, Asia, and South Africa [1]. Thirty-four species of this genus are distributed in Iran. Among them, Artemisia splendens Wild. is commonly known as "Asia minor wormwood" and "Dermane derakhshan" in Persian. This species is one of the most popular herbs in traditional medicine and is mostly used for the treatment of diseases like malaria, hepatitis, cancers, and inflammations. Afshar et al. reported that the main volatile compounds of $A$. splendens were 1,8-cineol (4.7\%), caryophyllene oxide (3.8\%), valencene (3.5\%) and $\alpha$-terpinyl acetate (3.4\%) [6]. In addition, Kazemi et al,. indicated that the major constituents of $A$. splendens were 1,8-cineole

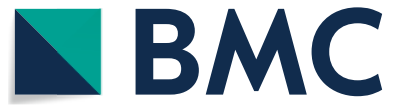

(C) The Author(s) 2021. This article is licensed under a Creative Commons Attribution 4.0 International License, which permits use, sharing, adaptation, distribution and reproduction in any medium or format, as long as you give appropriate credit to the original author(s) and the source, provide a link to the Creative Commons licence, and indicate if changes were made. The images or other third party material in this article are included in the article's Creative Commons licence, unless indicated otherwise in a credit line to the material. If material is not included in the article's Creative Commons licence and your intended use is not permitted by statutory regulation or exceeds the permitted use, you will need to obtain permission directly from the copyright holder. To view a copy of this licence, visit http://creativeco mmons.org/licenses/by/4.0/. The Creative Commons Public Domain Dedication waiver (http://creativecommons.org/publicdomain/ zero/1.0/) applies to the data made available in this article, unless otherwise stated in a credit line to the data. 
(14.5\%), germacrene $\mathrm{D}(14.3 \%), \alpha$-pinene $(11.3 \%)$ and bicyclogermacrene (11.3\%)[7]. However, their chemical composition has not hitherto been described. Thus, the aim of this study was to analyze the chemical constituents of methanolic fractions obtained from the aerial parts of A. splendens to exert antimicrobial activity and cytotoxic effects on cancerous cells.

\section{Material and methods} Plant material

Artemisia splendens aerial parts were collected from Arasbaran, at E: $31^{\circ} 49^{\prime} 46^{\prime \prime}, \mathrm{N}: 10^{\circ} 49^{\prime} 38^{\prime \prime}$ (altitude of 2470) East Azerbaijan Province, Iran in 2015. The plant material was identified by botanist Dr. Fatemeh Ebrahimi and the voucher specimen of the plant was deposited at the Herbarium of Faculty of Pharmacy, Tabriz University of Medical Sciences, Tabriz, Iran, under the registry code Tbz-FPh 717.

\section{Extraction}

Air-dried aerial parts (100 g) were ground and extracted in a Soxhlet apparatus using $\mathrm{MeOH}$. The extract was concentrated under the vacuum by a rotary evaporator at $45{ }^{\circ} \mathrm{C}$ and stored under refrigeration before analysis and biological evaluation.

\section{Fractionation of methanolic extract}

Two grams of the $\mathrm{MeOH}$ extract were fractionated on Sep-Pak ${ }^{\mathrm{TM}}$ Vac 35 cc (10 g) C18 cartridge (Waters) eluting with a step gradient of $\mathrm{MeOH}-\mathrm{H}_{2} \mathrm{O}$ mixtures (10:90, 20:80, 40:60, 60:40, 80:20, 100:0). A rotary evaporator was used to remove solvents at $45{ }^{\circ} \mathrm{C}$ under a vacuum. The procedure was repeated to increase the amount of SPE fractions.

\section{Isolation and identification of compounds}

The pure compounds of $(60: 40)$ methanolic fractions were collected according to the method described by Afshar et al. [8], using preparative reversed-phase HPLC (Knauer, preparative pump 1800), with photodiode array detector (PDA) (Fig. 1). The flow rate was $8 \mathrm{ml} / \mathrm{min}$ and the injection volume was $1 \mathrm{ml}$. Furthermore, 40\% SPE fraction was subjected to preparative reversed-phase HPLC using the following gradient elution: $0-30 \mathrm{~min}$, linear gradient of $40-60 \% \mathrm{MeOH}$ in water; $30-35 \mathrm{~min}$, maintained in $60 \% \mathrm{MeOH}$ in water; $35-38$ min, linear gradient from 60 to $100 \% \mathrm{MeOH}$ in water; 38-41 min, maintained in $100 \% \mathrm{MeOH}$; $41-43 \mathrm{~min}$, linear gradient from 100 to $40 \% \mathrm{MeOH}$ in water; $43-45 \mathrm{~min}$, maintained in $40 \% \mathrm{MeOH}$ in water; flow-rate: $8.0 \mathrm{~mL} / \mathrm{min}$ and injection volume was $1 \mathrm{ml}$. Detection was done by a photo-diode-array detector (PDA) at 220 and $280 \mathrm{~nm}$. This method allowed us to obtain astragalin

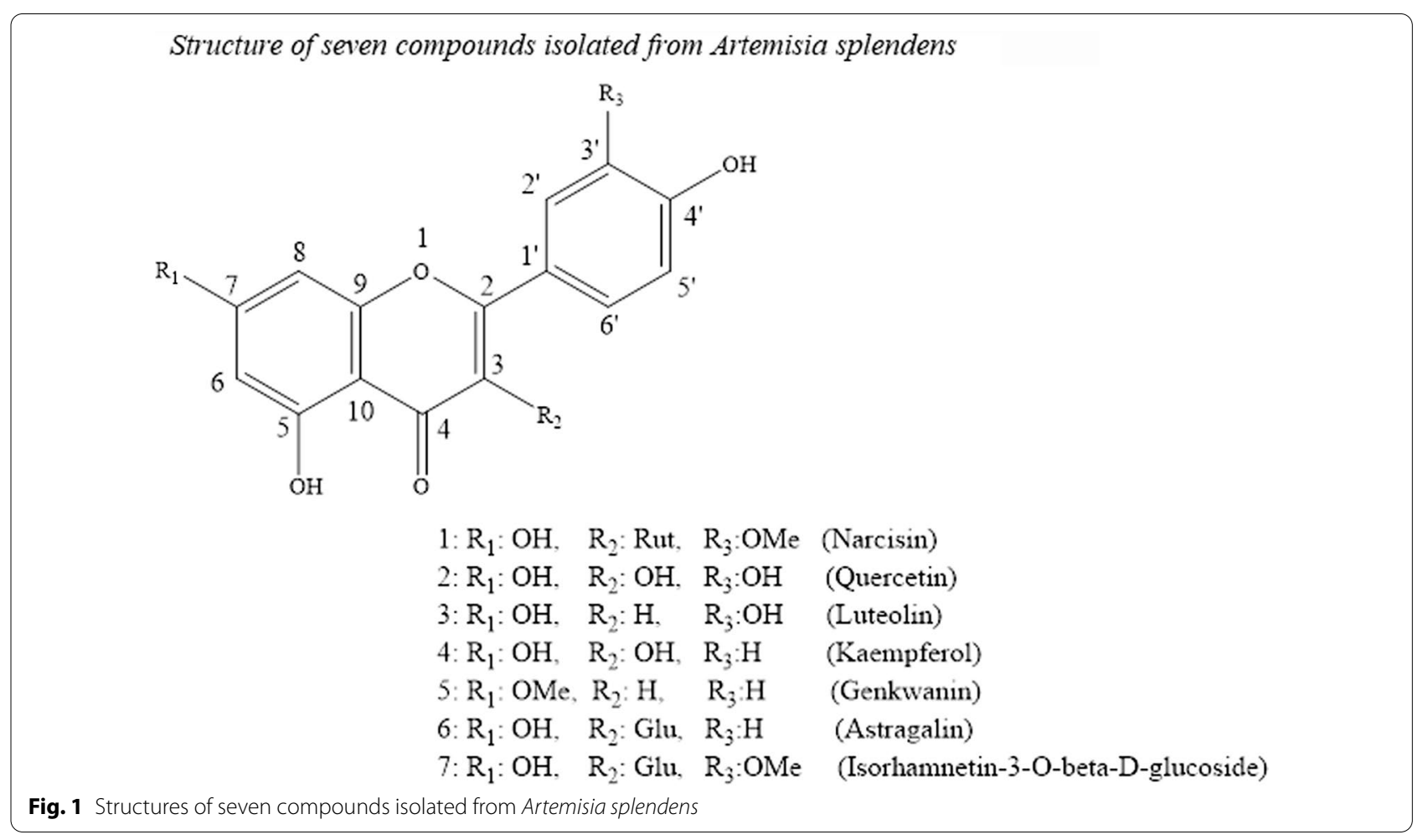


[6], isorhamnetin-3-O-beta-D-glucoside [7] and narcisin [9]. Structures of compounds were elucidated by the literature data of respective compounds [3, 6-9]. Moreover, shift reagents in UV method were used [10] as follows: sodium methoxide ( $\mathrm{NaOMe}$ ) (Merck), aluminum chloride $\left(\mathrm{AlCl}_{3}\right)$, aluminum chloride/ hydrochloric acid $\left(\mathrm{AlCl}_{3} / \mathrm{HCl}\right)$ (Merck) sodium acetate $(\mathrm{NaOAc})$ and sodium acetate/boric acid $\left(\mathrm{NaOAc} / \mathrm{H}_{3} \mathrm{BO}_{3}\right)$ (Merck).

\section{Anti-proliferative activity Cell culture}

HT-29 (colon carcinoma cell line) and A549 (adenocarcinoma human alveolar basal epithelial cells) cell lines were prepared and cultured according to described method by Afshar et al. [11]. At 75\% confluence, the cells were washed by phosphate-buffered saline (PBS) and cultured in 96-well plates (Nunc, Denmark) for MTT experiment.

\section{MTT assay}

The anti-cancer effect of the $\mathrm{MeOH}$ extract of $A$. splendens and its fractions were evaluated by MTT reduction colorimetric assay. The cells were cultured in a 96-well plate at a density of $1 \times 10^{4}$ cells/well and incubated for $24 \mathrm{~h}$. Cells were treated with different concentrations of extract and fractions which were prepared in dimethyl sulfoxide (DMSO). After $48 \mathrm{~h}$ of incubation, the medium was discarded and 3-(4,5-dimethylthiazol-2-yl)-2,5-diphenyltetrazolium bromide (MTT) solution $(5 \mathrm{mg} / \mathrm{ml}$ in PBS) was added to each well and incubated at $37^{\circ} \mathrm{C}$ and $5 \% \mathrm{CO}_{2}$ for $4 \mathrm{~h} \mathrm{[12].} \mathrm{The} \mathrm{medium} \mathrm{was} \mathrm{removed} \mathrm{and} \mathrm{then}$ DMSO was added to dissolve purple insoluble formazan. The wells were shaken for $5 \mathrm{~min}$ and then the optical density of each well was determined at $570 \mathrm{~nm}$ wavelength by a microplate reader (ELISA plate reader, Bio Teck, Bad Friedrichshall, Germany). Each assay was accomplished three times for each cell line. Antiproliferative activity of extracts and their fractions were measured by relative viability according to the method described by Afshar et al. [11].

\section{Antimicrobial activity Microbial strains}

The following lyophilized forms of microbial cultures purchased from Pasture Institute, Tehran, Iran were used in this study: Gram-negative Pseudomonas aeruginosa (ATCC 9027) and Escherichia coli (ATCC 8739), Grampositive Staphylococcus epidermidis (ATCC 12228), Staphylococcus aureus (ATCC 6538), and yeast Candida albicans (ATCC 10231).

\section{Disc diffusion test}

Activated microorganisms were transferred into MullerHinton broth medium (Merck, Germany) and incubated overnight at $37{ }^{\circ} \mathrm{C}$. For providing an optical density of 0.5 McFarland $\left(10^{8} \mathrm{CFU} / \mathrm{mL}\right.$ as a standard optical density) of bacterial concentration, the centrifuged pellets (3000 rpm for $15 \mathrm{~min}$ ) were washed twice and suspended in saline solution. The ultimate concentration of inocula was set up to $10^{6} \mathrm{CFU} / \mathrm{mL}$ with sterile saline solution. To achieve unified microbial growth, $10 \mathrm{~mL}$ of prepared inoculum suspensions were seeded in the autoclaved Muller-Hinton agar medium. Sterile discs (Whatman paper no. $6 \mathrm{~mm}$ diameter) located on the surface of media, were impregnated with $50 \mu \mathrm{L}$ of different concentrations of extracts $(1: 1,1: 5,1: 10)$ which were dissolved in $50 \%$ aqueous DMSO. Then they were imbued with a 0.5 McFarland's standard of mentioned bacteria covering 3 disks for test samples, one disk was used for negative control (including antimicrobial extracts and culture medium) and one disk was used for the positive control (including 0.5 McFarlend of the pathogen and culture medium). Afterward, for incubation and analysis, 100 $\mu \mathrm{L}$ of test solutions were poured into respective wells $(200 \mathrm{mg} / \mathrm{mL})$. The plates were transferred into the refrigerator to allow the diffusion of extracts approximately for $30 \mathrm{~min}$, and then petri dishes were incubated at $37^{\circ} \mathrm{C}$ for $24 \mathrm{~h}$. Finally, the diameter of the inhibition zones obtained nearby each well (excluding well diameter), showing no bacterial growth, was measured with venire caliper. Doublet plates were prepared for each sample. Extracts and fractions displaying considerable antimicrobial effects were further evaluated for their minimum inhibitory concentration (MIC), which is the lowest concentration of each product for completely inhibition of the bacterial growth [13]. Successively, two-fold dilutions of $\mathrm{MeOH}$ extract and its fractions were utilized in broth. The pure sterile nutrient broth was used as control. MIC values were calculated after $24 \mathrm{~h}$ incubating the plates at $37^{\circ} \mathrm{C}[14]$.

\section{Statistical analysis}

All statistical analyses were done using Graph Pad Prism 8.01 and SigmaPlot 11 software. One Way ANOVA with a post hoc Tukey test was used for evaluating significant differences between groups. The experiments were performed in triplicates $(n=3)$ and all data were presented as mean \pm S.D. $P$ values $<0.05$ which are regarded as significant.

\section{Results}

In the present study, the pure compounds $[1-7,9]$ obtained from SPE fractions have been assayed. Moreover, anti-proliferative and anti-microbial activities of the $\mathrm{MeOH}$ extract and its different SPE fractions from aerial parts of $A$. splendens were determined and the results are indicated in Tables 1, 2. (NMR spectroscopic data of 
compounds 1-8 $\left(\mathrm{CD}_{3} \mathrm{OD}\right.$, chemical shift $\delta$ in ppm, coupling constant $\mathrm{J}$ in $\mathrm{Hz}$ in parentheses):

Compound 1: ${ }^{1} \mathrm{HNMR}$ and ${ }^{13} \mathrm{CNMR}$ of the isorhamnetin-3-O-rutinoside was as follows: ${ }^{1} \mathrm{HNMR}(200 \mathrm{MHz}$, CD3OD): Aglycone moiety: $\delta 7.95\left(1 \mathrm{H}, \mathrm{d}, \mathrm{J}=2 \mathrm{~Hz}, \mathrm{H2} 2^{\prime}\right), \delta$ $7.65\left(1 \mathrm{H}, \mathrm{dd}, \mathrm{J}=8.48,2 \mathrm{~Hz}, \mathrm{H} 6^{\prime}\right), \delta 6.91(1 \mathrm{H}, \mathrm{d}, \mathrm{J}=8.48 \mathrm{~Hz}$, $\left.\mathrm{H} 5^{\prime}\right), \delta 6.42(1 \mathrm{H}, \mathrm{d}, \mathrm{J}=2 \mathrm{~Hz}, \mathrm{H} 8), \delta 6.22(1 \mathrm{H}, \mathrm{d}, \mathrm{J}=2 \mathrm{~Hz}$, H6), $\delta 3.59$ (3H, S, 3'-OMe). Glucose moiety: $\delta 5.24(1 \mathrm{H}$, $\mathrm{d}, \mathrm{J}=7.59 \mathrm{~Hz}, \mathrm{H} 1^{\prime \prime}$ ), 3.2-3.6 (signal patterns unclear due to over lapping, $\left.\mathrm{H} 2^{\prime \prime}-3^{\prime \prime}-4^{\prime \prime}-5^{\prime \prime}\right), \delta 3.90\left(2 \mathrm{H}, \mathrm{H}^{\prime \prime}\right), \delta 4.54$ $\left(\mathrm{l} \mathrm{H}, \mathrm{S}, \mathrm{Hl} \mathrm{l}^{\prime \prime}\right), 3.2-3.6$ (signal patterns unclear due to over lapping, $\left.\mathrm{H} 2^{\prime \prime \prime}-3^{\prime \prime \prime}-4^{\prime \prime \prime}-5^{\prime \prime \prime}\right) \delta 1.16(3 \mathrm{H}, \mathrm{d}, \mathrm{J}=5.61 \mathrm{~Hz}$, $\left.\mathrm{H} 66^{\prime \prime \prime}\right) .{ }^{13} \mathrm{CNMR}\left(50 \mathrm{MHz}, \mathrm{CD}_{3} \mathrm{OD}\right)$. Aglycone moiety: $\delta 177.5(\mathrm{C} 4), \delta 164.6$ (C7), $\delta 162.1$ (C5), $\delta 157.3$ (C9), $\delta$ $156.8(\mathrm{C} 2), \delta 149.8\left(\mathrm{C}^{\prime}\right), \delta 146.8\left(\mathrm{C}^{\prime}\right), \delta 134.3(\mathrm{C} 3), \delta$ $122.7\left(\mathrm{C}^{\prime}\right), \delta 121.3\left(\mathrm{C} 1^{\prime}\right), \delta 113.4\left(\mathrm{C}^{\prime}\right), \delta 115.3\left(\mathrm{C}^{\prime}\right), \delta$ 104.8 (C10), $\delta 98.3$ (C6), $\delta 93.5$ (C8), Glucose moiety: $\delta$ $102.7\left(\mathrm{C} 1^{\prime \prime}\right), \delta 76.7\left(\mathrm{C}^{\prime \prime}\right), \delta 76.1\left(\mathrm{C} 3^{\prime \prime}\right), \delta 72.5\left(\mathrm{C} 2^{\prime \prime}\right), \delta 71.0$ (C4"), $\delta 67.1$ (C6"), $\delta 55.3$ (OMe), $\delta 101.2\left(\mathrm{C} 1^{\prime \prime \prime}\right), \delta 74.5$ $\left(\mathrm{C}^{\prime \prime \prime}\right), \delta 70.8$ (C2'"), $\delta 70.5\left(\mathrm{C}^{\prime \prime \prime}\right), \delta 68.3\left(\mathrm{C}^{\prime \prime \prime}\right), \delta 16.5$ $\left(\mathrm{C6}^{\prime \prime \prime}\right)$.

Compound 2: ${ }^{1} \mathrm{HNMR}$ of quercetin was as follows: ${ }^{1}$ HNMR (200 MHz, CD3OD): $\delta 7.74(1 \mathrm{H}, \mathrm{d}, \mathrm{J}=1.91 \mathrm{~Hz}$, $\left.\mathrm{H} 2^{\prime}\right), \delta 7.66\left(1 \mathrm{H}, \mathrm{dd}, \mathrm{J}=8.40,1.91 \mathrm{~Hz}, \mathrm{H} 6^{\prime}\right), \delta 6.90(1 \mathrm{H}$, $\left.\mathrm{d}, \mathrm{J}=8.40 \mathrm{~Hz}, \mathrm{H}^{\prime}\right), \delta 6.40(1 \mathrm{H}, \mathrm{d}, \mathrm{J}=1.5 \mathrm{~Hz}, \mathrm{H} 8), \delta 6.18$ $(1 \mathrm{H}, \mathrm{d}, \mathrm{J}=1.5 \mathrm{~Hz}, \mathrm{H} 6)$.

Compound 3: ${ }^{1} \mathrm{HNMR}$ and ${ }^{13} \mathrm{CNMR}$ of luteolin was as follows: ${ }^{1} \mathrm{HNMR}(200 \mathrm{MHz}, \mathrm{CD} 3 \mathrm{OD}): \delta 7.38(\mathrm{l} \mathrm{H}$,

Table 1 Anti-proliferative activity of $\mathrm{MeOH}$ extract and its fractions against A549 and HT-29 cell lines

\begin{tabular}{lll}
\hline Samples & \multicolumn{1}{l}{$\mathbf{C}_{\mathbf{5 0}}(\boldsymbol{\mu \mathbf { g }} / \mathbf{m L})$} & \\
\cline { 2 - 3 } & $\mathbf{A 5 4 9}$ & $\mathbf{H T}-\mathbf{2 9}$ \\
\hline MeOH extract & $617.72 \pm 292.90$ & $>1000$ \\
10\% SPE fraction & $>1000$ & $>1000$ \\
20\% SPE fraction & $>1000$ & $>1000$ \\
40\% SPE fraction & $>1000$ & $>1000$ \\
60\% SPE fraction & $98.63 \pm 0.57$ & $487.18 \pm 38.06$ \\
80\% SPE fraction & $436.09 \pm 194.17$ & $>1000$ \\
100\% SPE fraction & $>1000$ & $920.2 \pm 62.50$ \\
\hline
\end{tabular}

d, H6 $\left.{ }^{\prime}\right), \delta 7.37\left(1 \mathrm{H}, \mathrm{S}, \mathrm{H} 2^{\prime}\right), \delta 6.90(1 \mathrm{H}, \mathrm{d}, \mathrm{J}=8.92 \mathrm{~Hz}$, $\left.\mathrm{H} 5^{\prime}\right), \delta$ 6.54(1H, S, H3), $\delta 6.44(1 \mathrm{H}, \mathrm{S}, \mathrm{H} 8), \delta 6.21(1 \mathrm{H}$, $\mathrm{S}, \mathrm{H6}) .{ }^{13} \mathrm{CNMR}\left(50 \mathrm{MHz}, \mathrm{CD}_{3} \mathrm{OD}\right): \delta 182.4(\mathrm{C} 4), \delta$ 164.7 (C7), $\delta 164.6$ (C2), $\delta 162.1$ (C5), $\delta 158.0$ (C9), $\delta$ 104.1 (C10), $\delta 102.4$ (C3), $\delta 98.7$ (C6), $\delta 93.6$ (C8), $\delta$ $149.6\left(\mathrm{C}^{\prime}\right), \delta 145.6\left(\mathrm{C} 3^{\prime}\right), \delta 122.2\left(\mathrm{C}^{\prime}\right), \delta 118.9\left(\mathrm{C} 1^{\prime}\right), \delta$ $115.3\left(\mathrm{C}^{\prime}\right), \delta 112.7\left(\mathrm{C}^{\prime}\right)$. UV spectrum bands II and I respectively $\left(\mathrm{MeOH}, \lambda_{\max }, \mathrm{nm}\right): 257,368 ;+\mathrm{NaOMe} 249$, $405 ;+\mathrm{AlCl}_{3} 272,440 ;+\mathrm{AlCl}_{3} / \mathrm{HCl} 268,420 ;+\mathrm{NaOAc}$ 270,$390 ;+\mathrm{NaOAc} / \mathrm{H}_{3} \mathrm{BO}_{3}$ 262, 380. The UV spectrum of compound 5 with $\mathrm{MeOH}$ as a solvent is characteristic of flavones derivatives. Studying UV spectra data after the addition of $\mathrm{NaOMe}$ and production of $37 \mathrm{~nm}$ band I bathochromic shift is indicative of $4^{\prime}-\mathrm{OH}$. After $5 \mathrm{~min}$, no destruction of band $\mathrm{I}$ is showed that no moiety on $\mathrm{C}_{3}$ was observed. The addition of $\mathrm{AlCl}_{3}$ produced $72 \mathrm{~nm}$ band I bathochromic shift, so ortho di-hydroxyl structure of a compound can be elucidated and free $5-\mathrm{OH}$ position of flavonoid is indicated as well. The addition of $\mathrm{NaOAc}$ and production of band II bathochromic shift of $13 \mathrm{~nm}$ indicated the free 7-OH position of flavonoid. After the addition of $\mathrm{H}_{3} \mathrm{BO}_{3}$, and production of $12 \mathrm{~nm}$ bathochromic shift on band I confirmed the presence of ortho dihydroxyl structure.

Compound 4: ${ }^{1} \mathrm{HNMR}$ and ${ }^{13} \mathrm{CNMR}$ of kaempferol was as follows: HNMR (200 MHz, CD3OD): $\delta 8.10(2 \mathrm{H}$, $\left.\mathrm{d}, \mathrm{J}=8.70 \mathrm{~Hz}, \mathrm{H} 2^{\prime}, 6^{\prime}\right), \delta 6.90\left(2 \mathrm{H}, \mathrm{d}, \mathrm{J}=8.70 \mathrm{~Hz}, \mathrm{H3}{ }^{\prime}, 5^{\prime}\right)$, $\delta 6.41(1 \mathrm{H}, \mathrm{d}, \mathrm{J}=1.44 \mathrm{~Hz}, \mathrm{H} 8), \delta 6.19(1 \mathrm{H}, \mathrm{d}, \mathrm{J}=1.83 \mathrm{~Hz}$, H6). ${ }^{13} \mathrm{CNMR}(50 \mathrm{MHz}, \mathrm{CD} 3 \mathrm{OD}): \delta 129.3\left(\mathrm{C} 2^{\prime}, 6^{\prime}\right), \delta$ $114.9\left(\mathrm{C}^{\prime}, 5^{\prime}\right), \delta 98.2(\mathrm{C} 6), \delta 93.1(\mathrm{C} 8)$,

Compound 5: ${ }^{1} \mathrm{HNMR}$ and ${ }^{13} \mathrm{CNMR}$ of genkwanin was as follows: ${ }^{1} \mathrm{HNMR}(200 \mathrm{MHz}, \mathrm{CD} 3 \mathrm{OD}): 7.85(2 \mathrm{H}, \mathrm{d}$, $\left.\mathrm{J}=8.80 \mathrm{~Hz}, \mathrm{H} 2^{\prime}, 6^{\prime}\right), \delta 6.93\left(2 \mathrm{H}, \mathrm{d}, \mathrm{J}=8.80 \mathrm{~Hz}, \mathrm{H} 3^{\prime}, 5^{\prime}\right)$, $\delta 6.66(1 \mathrm{H}, \mathrm{S}, \mathrm{H} 3), \delta 6.48(1 \mathrm{H}, \mathrm{d}, \mathrm{J}=1.74 \mathrm{~Hz}, \mathrm{H} 8), \delta 6.21$ $(1 \mathrm{H}, \mathrm{d}, \mathrm{J}=1.74 \mathrm{~Hz}, \mathrm{H} 6), \delta 3.97(3 \mathrm{H}, \mathrm{S}, \mathrm{OMe}) .{ }^{13} \mathrm{CNMR}$ (50 MHz, CD3OD): $\delta 164.0$ (C7), $\delta 157.1$ (C5), 128.0 $\left(\mathrm{C}^{\prime}, 6^{\prime}\right), \delta 115.6\left(\mathrm{C}^{\prime}, 5^{\prime}\right), \delta 103.8(\mathrm{C} 3), \delta 98.8(\mathrm{C} 6), \delta$ 94.4 (C8), $\delta 55.6$ (C3 OMe). UV spectrum bands II and I respectively $\left(\mathrm{MeOH}, \lambda_{\max }, \mathrm{nm}\right): 271,350 ;+\mathrm{NaOMe} 266$, $405 ;+\mathrm{AlCl}_{3} 276,390 ;+\mathrm{AlCl}_{3} / \mathrm{HCl} 278,387 ;+\mathrm{NaOAc}$ 273,$363 ;+\mathrm{NaOAc} / \mathrm{H}_{3} \mathrm{BO}_{3} 270$, 348. UV spectrum of

Table 2 Anti-microbial activity of Methanolic extract and 40\% MeOH-water SPE fraction of aerial parts of A. splendens

\begin{tabular}{|c|c|c|c|c|c|c|}
\hline \multirow[t]{2}{*}{ Samples } & & \multicolumn{5}{|c|}{ Microorganisms } \\
\hline & & E. coli & P. aeruginosa & S. epidermidis & S. aureus & C. albicans \\
\hline \multirow[t]{2}{*}{ Methanolic extract } & $\mathrm{DIZ}($ Mean $\pm \mathrm{SD})(\mathrm{mm})$ & - & - & $12.5 \pm 0.7$ & $28.5 \pm 2.1$ & - \\
\hline & $\mathrm{MIC}, \mathrm{mg} / \mathrm{mL}$ & - & - & 200 & 100 & - \\
\hline \multirow{2}{*}{$40 \% \mathrm{MeOH}$-water SPE fraction } & $\mathrm{DIZ}($ Mean $\pm \mathrm{SD})(\mathrm{mm})$ & - & - & $9.5 \pm 0.70$ & $11 \pm 0.00$ & - \\
\hline & $\mathrm{MIC}, \mathrm{mg} / \mathrm{mL}$ & - & - & - & - & - \\
\hline
\end{tabular}


compound 5 confirmed the structure of Genkwanin as well.

Compound 6: ${ }^{1} \mathrm{HNMR}$ and ${ }^{13} \mathrm{CNMR}$ of Astragaline was as follows: HNMR (200 MHz, CD3OD): $\delta 8.07(2 \mathrm{H}$, $\left.\mathrm{d}, \mathrm{J}=8.81 \mathrm{~Hz}, \mathrm{H} 2^{\prime}, 6^{\prime}\right), \delta 6.93\left(2 \mathrm{H}, \mathrm{d}, \mathrm{J}=8.81 \mathrm{~Hz}, \mathrm{H} 3^{\prime}, 5^{\prime}\right)$, $\delta 6.41(1 \mathrm{H}, \mathrm{d}, \mathrm{J}=2.00 \mathrm{~Hz}, \mathrm{H} 8), \delta 6.21(1 \mathrm{H}, \mathrm{d}, \mathrm{J}=2.00 \mathrm{~Hz}$, H6). ${ }^{13} \mathrm{CNMR}(50 \mathrm{MHz}, \mathrm{CD} 3 \mathrm{OD}): \delta 130.93\left(\mathrm{C}^{\prime}, 6^{\prime}\right), \delta$ $114.81\left(\mathrm{C}^{\prime}, 5^{\prime}\right), \delta 98.2(\mathrm{C} 6), \delta 93.1(\mathrm{C} 8), \delta 62.10-76.40$ $\left(\mathrm{C} 6^{\prime \prime}-\mathrm{C} 2^{\prime \prime}\right)$.

Compound 7: ${ }^{1} \mathrm{HNMR}$ and ${ }^{13} \mathrm{CNMR}$ of Isorhamnetin-3-O-beta-D-glucoside was as follows: HNMR $(200 \mathrm{MHz}, \mathrm{CD} 3 \mathrm{OD}): \delta 7.94\left(1 \mathrm{H}, \mathrm{d}, \mathrm{H} 2^{\prime}\right), \delta 7.59(1 \mathrm{H}$, d, J $\left.=7.54 \mathrm{~Hz}, \mathrm{H6}^{\prime}\right), \delta 6.91\left(1 \mathrm{H}, \mathrm{d}, \mathrm{J}=7.54 \mathrm{~Hz}, \mathrm{H} 5^{\prime}\right), \delta$ $6.41(1 \mathrm{H}, \mathrm{d}, \mathrm{J}=2.00 \mathrm{~Hz}, \mathrm{H} 8), \delta 6.21(1 \mathrm{H}, \mathrm{d}, \mathrm{J}=2.00 \mathrm{~Hz}$, H6), $\delta 5.43\left(1 \mathrm{H}, \mathrm{d}, \mathrm{J}=6.35 \mathrm{~Hz}, \mathrm{H} 1^{\prime \prime}\right) . \delta 3-4(5 \mathrm{H}, \mathrm{d}, 5$ $\left.\mathrm{H} 2{ }^{\prime \prime}-\mathrm{H} 6{ }^{\prime \prime}\right) .{ }^{13} \mathrm{CNMR}$ (50 MHz, CD3OD): $\delta 178.80$ (C4), $\delta$ 164.60 (C7), $\delta 158.80$ (C2), $\delta 163.50$ (C5), $\delta 160.00$ (C9), $\delta 103.90$ (C10), $\delta 130.90$ (C3), $\delta 98.40$ (C6), $\delta 93.30$ (C8), $\delta 146.80\left(\mathrm{C}^{\prime}\right), \delta 151.90\left(\mathrm{C}^{\prime}\right), \delta 122.30\left(\mathrm{C}^{\prime}\right), \delta 121.10$ $\left(\mathrm{C} 1^{\prime}\right), \delta 114.60\left(\mathrm{C}^{\prime}\right), \delta 112.9\left(\mathrm{C} 2^{\prime}\right), \delta 102.10\left(\mathrm{C}^{\prime \prime}\right), \delta$ 61.90- $72.90\left(\mathrm{C6}^{\prime \prime}-\mathrm{C} 2^{\prime \prime}\right)$.

Compound 8: This compound was named as Narcisin. The NMR data was the same as compound 1 .

\section{Cytotoxic assay}

In our study, the $\mathrm{MeOH}$ extract of $A$. splendens and its fractions were investigated for their cell growth inhibitory effect in human tumor cell lines such as HT-29 and A549 by MTT assay. The $\mathrm{IC}_{50}$ values of corresponding extract and fractions are reported in Table 1. The results indicated that the methanolic extract had weak to moderate anti-proliferative activity on the A549 cell line in comparison with DMSO control $(P<0.001)$ with an $\mathrm{IC}_{50}$ value of $617.72 \pm 292.90 \mu \mathrm{g} / \mathrm{mL}$. Whereas (10:90), (20:80), (40:60) MeOH: water SPE fractions did not affect the growth of A549 cells, $60 \%$ fraction inhibited cell growth of A549 cell line compared with control $(P<0.001)$ with an $\mathrm{IC}_{50}$ value of $98.63 \mu \mathrm{g} / \mathrm{mL}$. In terms of colon cancer cell line, although, $\mathrm{MeOH}$ extract, could not decrease the amounts of cancer cells, its 60\% SPE fraction significantly indicated anti-proliferative activity $(P<0.001)$.

\section{Anti-microbial activity}

Among all the strains, only inhibition zones were observed against gram-positive S. epidermidis and $S$. aureus (Table 2). The MIC values for S. epidermidis was $200 \mathrm{mg} / \mathrm{mL}$ and for $S$. aureus $100 \mathrm{mg} / \mathrm{mL}$ which considered as very weak activity compared to the control by $\mathrm{MeOH}$ extract and 40\% SPE fraction.

\section{Discussion}

Cancer is one of the diseases with the highest mortality rate in developed countries and the second leading cause of death in developing countries [15]. Among all cancer types, lung and colon cancers are the most commonly diagnosed cancers in both genders [16]. Furthermore, due to the adverse effects of anti-microbial chemical drugs, the use of plants with anti-microbial effects is recommended to reduce side effects. Different studies have revealed that herbal medicines have anti-proliferative and anti-microbial activities through different functional mechanisms [17]. In the current study, the cytotoxic and anti-microbial effects of $\mathrm{MeOH}$ extract and its SPE fractions of A. splendens on A549 and HT-29 cells and different microorganisms have been investigated.

The results showed that $60 \%$ SPE fraction of $\mathrm{MeOH}$ extract had weak to moderate cytotoxic effect on both tumor cells in comparison with other fractions and $\mathrm{MeOH}$ extract as well as control $(P<0.001)$. It is worth mentioning that even though HT-29 was not influenced by $\mathrm{MeOH}$ extract, its $60 \%$ SPE fraction inhibited the growth of cells $(P<0.001)$. It can be concluded that the main anti-cancer ingredients of this extract have been accumulated in this fraction. Chromatographic separation of this fraction afforded 5 known flavonoids, namely isorhamnetin-3-O-rutinoside, quercetin, luteolin, kaemferol and genkwanin which are reported in this species for the first time. The anti-proliferative activity of various species of Artemisia has been evaluated by several researchers. These extracts inhibited the growth of different cell lines such as T47D, MCF-7 by inducing apoptosis [18]. Furthermore, previous studies have shown that quercetin and luteolin have cytotoxic effects on $\mathrm{A} 549$ with an $\mathrm{IC}_{50}$ value of 10.0 and $3.1 \mu \mathrm{M}$, respectively [19]. Luteolin induces apoptosis through the downregulation of several apoptotic proteins in HT-29 [20]. It has been reported that kaempferol treatment promotes apoptosis of HT-29 human colon cancer cells through both extrinsic and intrinsic pathways [21]. Additionally, the $\mathrm{IC}_{50}$ value of genkwanin on $\mathrm{A} 549$ was determined as $9 \mu \mathrm{M}$ [22]. A combination of solid-phase-extraction (SPE) and reversed-phase prep-HPLC analysis of the aerial parts of the SPE fraction (60\%) afforded five flavonoids, which were isorhamnetin-3-O-rutinoside, quercetin, luteolin, kaempferol, and genkwanin. Structural identification of isolated phytochemicals was carried out by UV and NMR analysis and comparison of the data with the reported values. According to our knowledge, none of these phenolic compounds were isolated from A. splendens. Although in prior studies some compounds such as melilotoside have been reported from this plant [23].

The $1 \mathrm{H}$-NMR spectrum of compound 1 , revealed a doublet resonance at $\delta 7.95(1 \mathrm{H}, \mathrm{d}, 2.0)$ was specified for 
$\mathrm{H}-2^{\prime}$. The doublets at $7.65(\mathrm{~J}=1.70,8.40 \mathrm{~Hz})$ and 6.91 $(\mathrm{J}=8.40 \mathrm{~Hz})$ indicated ortho-coupled aromatic $\mathrm{H}$-atoms assignable to $H\left(6^{\prime}\right)$ and $H\left(5^{\prime}\right)$, respectively. Besides, doublet resonances at $\delta 6.22(1 \mathrm{H}, 2.0)$ and $\delta 6.42(1 \mathrm{H}, 2.0)$ for the $H(6)$ and $H(8)$, indicated the meta coupled connection. Furthermore, doublet resonance at $\delta$ 5.24 showed the presence of an anomeric proton of glucose. The presence of singlet resonance at $\delta 4.54$ and doublet resonance at $\delta 1.11(\mathrm{~J}=6.04 \mathrm{~Hz})$ is indicative of anomeric proton and $\mathrm{CH}_{3}\left(\mathrm{C}_{6}\right)$ of rhamnose, respectively. Mentioned data are consistent with the isorhamnetin-3-O-rutinoside (Narcissin) structure which has been proved by the previously published papers. The presence of this compound has been observed in other species of Artemisia such as $A$. sublessingiana, $A$. absinthium, $A$. vulgaris, and $A$. incana $[24,25]$.

In terms of compound 2 (quercetin), the UV spectrum of this compound indicated the presence of OH- 4 ' and 3 moieties due to bathochromic shift of band I and destruction of it after $5 \mathrm{~min}$. The addition of $\mathrm{AlCl}_{3}$ reagent and observing a bathochromic shift in band I has been proved the presence of sensitive and resistant moieties of this structure. Subsequently, by adding HCL, the hypsochromic shift compared to the $\mathrm{AlCl}_{3}$ graph as well as a bathochromic shift to the $\mathrm{MeOH}$ graph illustrated the existence of both sensitive moieties (ortho dihydroxy of $3^{\prime}, 4^{\prime}$ ) and resistant ones (free 3-OH and 5-OH). Furthermore, ${ }^{1} \mathrm{H}$ and ${ }^{13} \mathrm{C}$-NMR spectrum have been proved this structure as well. All of the mentioned data are consistent with many previous investigations as well [26]. Spectrum data of compound 4, completely are in line with compound 2, except little difference in $\mathrm{B}$ ring with a symmetric structure in which the spectrum data are in line with published papers [27]. In the case of compounds (3) and (5), UV spectra were identical with flavone structure, (which was supported by ${ }^{1} \mathrm{H}-\mathrm{NMR}$ and ${ }^{13} \mathrm{C}-\mathrm{NMR}$ spectrums, showing characteristic signals appeared at $\delta$ 6.54 $(1 \mathrm{H}, \mathrm{s}, \mathrm{H}-3), 6.66(1 \mathrm{H}, \mathrm{s}, \mathrm{H}-3)$, luteolin, and genkwanin, respectively $[26,28]$.

$\mathrm{MeOH}$ extract and $40 \%$ SPE fraction of this plant showed inhibition zones against S. epidermidis and $S$. aureus. Although the MIC values for these pathogens are 100 and $200 \mathrm{mg} / \mathrm{ml}$ which considered as weak to inactive. It seems that it can be achieved potent anti-microbial agents via more isolating compounds from $\mathrm{MeOH}$ extract and 40\% SPE fraction. Furthermore, in extract and fractions due to there are broad ranges of compounds, different biological activity might be observed (because the compounds have synergist or antagonist activity with each other). Previous studies showed $\mathrm{MeOH}$ extract of $A$. nilagirica indicated inhibitory activity against Gram-positive, as well as Gram-negative with DIZ value of $12 \mathrm{~mm}$ [29]. Furthermore, the $\mathrm{MeOH}$ extract of A. nilagirica was active against $M$. smegmatis [30]. Buffered methanol (80\% methanol and 20\% PBS) and acetone extracted substances from $A$. absinthium were active against $E$. coli, $S$. infantis, S. aureus, and L. monocytogenes [31]. A. capillaris Thunb. and A. caruifolia Buch. demonstrated inhibitory activity against $B$. cereus and L. monocytogenes [32]. $A$. annua and $A$. vulgaris $\mathrm{L}$. illustrated the most prominent anti-bacterial activity against $S$. mutans [33].

To the best of our knowledge, no data were available on the antimicrobial activity of $A$. splendens $\mathrm{MeOH}$ extract. $40 \%$ SPE fraction for bearing moderate inhibitory effect on microorganisms was selected for further investigation using prep-HPLC afforded three main compounds as following structure. Compound 6 was isolated as yellow needles. HRESIMS analyses (positive and negative ion modes) of compound 1 revealed the pseudo-molecular ions at $\mathrm{m} / \mathrm{z} 471[\mathrm{M}+\mathrm{Na}]^{+}$and $447[\mathrm{M}-\mathrm{H}]^{-}$, which was in agreement with the molecular formula $\mathrm{C}_{21} \mathrm{H}_{20} \mathrm{O}_{11} \mathrm{Na}$ and $\mathrm{C}_{21} \mathrm{H}_{19} \mathrm{O}_{11}$, respectively. The ${ }^{1} \mathrm{H}$-NMR spectrum of compound 1 revealed the doublets resonance at $\delta 8.07$ $(2 \mathrm{H}, \mathrm{d}, \mathrm{J}=8.81 \mathrm{~Hz})$ and $\delta 6.93(2 \mathrm{H}, \mathrm{d}, \mathrm{J}=8.81 \mathrm{~Hz})$ were specified for $\mathrm{H}-2^{\prime}, \mathrm{H}-\mathrm{G}^{\prime}$ and $\mathrm{H}-3^{\prime}, \mathrm{H}-5^{\prime}$, respectively. In addition, doublet resonances at $\delta 6.41(1 \mathrm{H}, \mathrm{d}, \mathrm{J}=2.00 \mathrm{~Hz})$ and $\delta 6.21(1 \mathrm{H}, \mathrm{d}, \mathrm{J}=2.00 \mathrm{~Hz})$ for the $\mathrm{H}-8$ and $\mathrm{H}-6$, indicated the meta coupled connections, correspondingly. The above-mentioned data suggesting the presence of a flavonoid structure with a para pattern in the B ring. In addition, the ${ }^{1} \mathrm{H}$-NMR spectra of compound 6 confirmed the presence of an overlapping signal for five protons $(\delta 3-4 \mathrm{ppm})$ and an anomeric proton $(\delta 5.45,1 \mathrm{H}$, $\mathrm{d}, \mathrm{J}=7.48 \mathrm{~Hz}$ ) corresponding to a glucosyl moiety with $\beta$ configuration. The UV spectrum of compound 1 with $\mathrm{MeOH}$ as a solvent is characteristic of flavonols derivatives. Studying UV spectra data after the addition of $\mathrm{NaOMe}$ and production of $60 \mathrm{~nm}$ band I bathochromic shift is indicative of $4^{\prime}-\mathrm{OH}$. Remaining of band I after 5 min indicated that $\mathrm{C}-3$ has substitution except for $\mathrm{OH}$. The addition of $\mathrm{AlCl}_{3} / \mathrm{HCl}$ did not cause any hypsochromic shift in the $\mathrm{AlCl}_{3}$ spectrum. Therefore, it can be concluded there is no ortho-dihydroxy group $\left(3^{\prime}\right.$ and $\left.4^{\prime}-\mathrm{OH}\right)$ in the $\mathrm{B}$ ring. Furthermore, it leads to the presence of $\mathrm{OH}$ in $\mathrm{C}-5$. Addition of $\mathrm{NaOAc}$ and production of band II bathochromic shift of $7 \mathrm{~nm}$ indicative of free 7-OH. In studying the ${ }^{13} \mathrm{C}$-NMR, the presence of four signals at $\delta$ $60-75$, confirms the presence of glucose in the composition. Moreover, signals at $\delta 130.93$ and 114.81 corresponded to $C-2^{\prime}, C-6^{\prime}$ and $C-3^{\prime}, C-5^{\prime}$, respectively. Thus, compound 6 was identified as Astragalin. All spectroscopic data were in good agreement with the literature data of respective compounds [34, 35]. While Astragalin [6] was previously reported from A. transiliensis [36] and A. annua, [3] this is the first report on the presence of Astragalin in the A. splendens. 
Compound 7 was isolated as a yellow amorphous powder. ESIMS and FABMS analyses (negative and positive ion modes) of compound 7 revealed the pseudo-molecular ions at $\mathrm{m} / \mathrm{z} 477[\mathrm{M}-\mathrm{H}]^{-}$and $479[\mathrm{M}+\mathrm{H}]^{+}$, which was in agreement with the molecular formula $\mathrm{C}_{22} \mathrm{H}_{21} \mathrm{O}_{12}$ and $\mathrm{C}_{22} \mathrm{H}_{23} \mathrm{O}_{12}$, respectively. The ${ }^{1} \mathrm{H}$-NMR spectrum of compound 7, revealed a singlet resonance at $\delta 7.94(1 \mathrm{H}$, s) was specified for $\mathrm{H}-2^{\prime}$. The doublets at $\delta 7.59(1 \mathrm{H}$, $\mathrm{d}, \mathrm{J}=7.54 \mathrm{~Hz})$ and $\delta 6.91(1 \mathrm{H}, \mathrm{d}, \mathrm{J}=7.54 \mathrm{~Hz})$ indicated ortho-coupled aromatic $\mathrm{H}$-atoms assignable to $\mathrm{H}-6^{\prime}$ and $\mathrm{H}-5^{\prime}$ in the $\mathrm{B}$ ring of flavonoid, respectively. In addition, doublet resonances at $\delta 6.41(1 \mathrm{H}, \mathrm{s})$ and $\delta 6.21(1 \mathrm{H}, \mathrm{s})$ for the H-8 and H-6 indicating the presence of the meta coupled connection. There was also a methoxy signal $(\delta \mathrm{H} 3.95,3 \mathrm{H}, \mathrm{s})$ that is indicative of $3^{\prime}-\mathrm{OCH}_{3}$. Although an anomeric proton $(\delta 5.43,1 \mathrm{H}, \mathrm{d})$ and some of the glycosidic protons overlapped ( $\delta 3-4 \mathrm{ppm})$ in the ${ }^{1} \mathrm{H}-\mathrm{NMR}$ spectrum, in studying the ${ }^{13} \mathrm{C}$-NMR, the presence of five signals at $\delta 60-75$ and a resonance at $\delta 102.1$ (anomeric carbon of glucose), confirms the presence of glucose in the composition. The presence of a signal at $\delta 55.3 \mathrm{ppm}$ in the ${ }^{13} \mathrm{C}$-NMR spectrum indicating a methoxy group which is confirmed by the presence of a singlet resonance at $\delta 3.95(3 \mathrm{H})$ in the ${ }^{1} \mathrm{H}$-NMR spectrum. In ${ }^{13} \mathrm{C}-\mathrm{NMR}$, signals at $\delta 178.80,164.60,163.50,160.00,158.80,130.90$, 103.90, 98.40 and 93.30 corresponded to C-4, C-7, C-5, C-9, C-2, C-3, C-10, C-6 and C-8, respectively. Furthermore, signals at $\delta 151.90,146.80,122.30,121.10,114.60$ and 112.9 corresponded to $C-3^{\prime}, C-4^{\prime}, C-6^{\prime}, C-1^{\prime}, C-5^{\prime}$ and $\mathrm{C}-2^{\prime}$, respectively. Thus, compound 7 was identified unequivocally as isorhamnetin-3-O-beta-D-glucoside. Spectroscopic data were in good agreement with the literature data of the respective compound [37]. While isorhamnetin-3-O-beta-D-glucoside was previously reported from $A$. halodendron, [38] this is the first report for reporting this compound from $A$. splendens. Compound 8 was also isolated as a light yellowish powder from a $60 \%$ fraction as well. FABMS analyses (negative and positive ion modes) of compound 8 revealed the pseudo-molecular ions at $\mathrm{m} / \mathrm{z} 623[\mathrm{M}-\mathrm{H}]^{-}$and $647[\mathrm{M}+\mathrm{Na}]^{+}$, which was in agreement with the molecular formula $\mathrm{C}_{28} \mathrm{H}_{31} \mathrm{O}_{16}$ and $\mathrm{C}_{28} \mathrm{H}_{32} \mathrm{O}_{16} \mathrm{Na}$, respectively. The ${ }^{1} \mathrm{H}-\mathrm{NMR}$ and ${ }^{13} \mathrm{C}-$ NMR spectra of compound 8 were similar to those of compound 7, with the exception that one more rhamnose moiety has been regarded to this compound with four protons signals $(\delta 3.2-3.6)$, doublet resonance at $\delta$ $1.11(3 \mathrm{H}, \mathrm{d}, \mathrm{J}=6.04 \mathrm{~Hz})$ and singlet resonance at $\delta 4.54$ $(1 \mathrm{H}, \mathrm{s})$, which is attributed to anomeric proton of $\mathrm{H}-1^{\prime \prime \prime}$ of rhamnose moiety. Furthermore, the ${ }^{1} \mathrm{H}-\mathrm{NMR}$ spectra of compound 8 verified the existence of one isorhamnetin nucleus. Our claim has been supported by methoxy group shift $(\delta 3.95,3 \mathrm{H}, \mathrm{s})$ in ${ }^{1} \mathrm{H}-\mathrm{NMR}$ as well as methoxy carbon signal $(\delta 55.30)$ at ${ }^{13} \mathrm{C}-\mathrm{NMR}$; In ${ }^{1} \mathrm{H}$-NMR two aromatic spin systems, $7.95(1 \mathrm{H}, \mathrm{d}, \mathrm{J}=1.70 \mathrm{~Hz}), 7.64(1 \mathrm{H}$, $\mathrm{dd}, \mathrm{J}=8.40$ and $1.70 \mathrm{~Hz})$ and $\delta 6.95(1 \mathrm{H}, \mathrm{d}, \mathrm{J}=8.40 \mathrm{~Hz})$ corresponded to $\mathrm{H}-2^{\prime}, \mathrm{H}-6^{\prime}$ and $\mathrm{H}-5^{\prime}$, respectively. Remaining peaks have been considered for $6.41(1 \mathrm{H}, \mathrm{s})$ $\mathrm{H}-8$ and $6.22(1 \mathrm{H}, \mathrm{s}) \mathrm{H}-6$.

The $1 \mathrm{H}-\mathrm{NMR}$ spectrum of compound 3 showed the presence of one glucosyl moieties with characteristic doublet resonance at $\delta 5.24(1 \mathrm{H}, \mathrm{d}, J=7.18 \mathrm{~Hz})$ for the anomeric proton of $\beta$-glucose. In addition, the ${ }^{1} \mathrm{H}$-NMR spectra of compound 1 confirmed the presence of overlapping signals for four protons $(\delta 3.2-3.6 \mathrm{ppm})$, an anomeric proton $(\delta 4.54,1 \mathrm{H}, \mathrm{s})$ and $\delta 1.11(3 \mathrm{H}, \mathrm{d}, 6.04)$ (methyl group of rhamnose), corresponding to a rhamnose moiety in the composition. In studying the ${ }^{13} \mathrm{C}$ NMR spectrum, the presence of five signals at $\delta 60-75$ and a resonance at $\delta 102.7$ (anomeric carbon of glucose), confirms the presence of glucose in the composition as well as the presence of four signals at $\delta 60-75$, presence of a signal at $\delta 101.2$ (anomeric carbon of rhamnose) and $\delta 16.5$ (methyl group of rhamnose), was confirmed the presence of rhamnose in the composition. Furthermore, signals at $\delta 177.50,164.60,162.10,157.30,156.80,134.30$, 104.80, 98.10 and 93.50 corresponded to C-4, C-7, C-5, C-9, C-2, C-3, C-10, C-6 and C-8, respectively; as well as, signals at $\delta 149.80,146.80,122.70,121.30,115.30$ and 113.40 corresponded to $C-3^{\prime}, C-4^{\prime}, C-6^{\prime}, C-1^{\prime}, C-2^{\prime}$ and $\mathrm{C}-5^{\prime}$, respectively. On the basis of these data, the structure of 8 was elucidated as narcissin. Finding a literature review of previous works was compatible with our results [39]. While isorhamnetin-3-O-beta-D-glucoside was previously reported from $A$. sublessingiana, A. absinthium, A. vulgaris [40] and A. incana, [41] to the best of our knowledge, the respective compound was detected in this specie for the first time.

\section{Conclusion}

In the current study, we reported the anti-proliferative and anti-microbial activities as well as chemical compositions of $60 \%$ and $40 \%$ SPE fractions which indicated maximum cytotoxic (against A549 and HT-29 cancerous cells) and inhibition zones against Gram-positive strains, respectively for the first time. Further analysis of both potent fractions afforded 5 flavonoids: narcisin (1), quercetin (2), luteolin (3), kaempferol (4) and genkwanin (5) from $60 \%$ SPE fraction as well as three known flavonoid glycosides, astragalin (6), isorhamnetin-3-O-betaD-glucoside (7) as well as narcisin (8) from 40\% SPE fraction for the first time from the $A$. splendens.

\footnotetext{
Acknowledgements

We would like to thank Dr. Baradaran for their supportive help in performing the anti-proliferative part.
} 


\section{Authors' contributions}

$F A H$ and $M Z$ performed the experiments; $Z R$ and $A D$ analyzed of data; $F A H$ $M Z$, ZR and AD prepared the manuscript; PA and VT wrote and edited the manuscript; PA designed the experiments; PA led and supervised the project. All authors read and approved the final manuscript

\section{Funding}

This work was supported and funded scheme by Faculty of Pharmacy, Tabriz University of Medical Sciences.

\section{Availability of data and materials}

The authors confirm that the data supporting the findings of this study are available within the article.

\section{Declarations}

\section{Ethics approval and consent to participate}

There is no involvement of human or animal in this study.

\section{Consent for publication}

All other authors declare no conflict of interest.

\section{Competing interests}

We declare that we have no significant competing financial, professional, or personal interests that might have influenced the performance or presentation of the work described in this manuscript.

\section{Author details}

${ }^{1}$ Biotechnology Research Center, Tabriz University of Medical Sciences, Tabriz, Iran. ${ }^{2}$ Student Research Committee, Tabriz University of Medical Sciences, Tabriz, Iran. ${ }^{3}$ Research institute of Bioscience and Biotechnology, University of Tabriz, Tabriz, Iran. ${ }^{4}$ Drug Applied Research Center, Tabriz University of Medical Sciences, Tabriz, Iran. ${ }^{5}$ Department of Pharmacognosy, Faculty of Pharmacy, Tabriz University of Medical Sciences, Tabriz, Iran. ${ }^{6}$ Molecular Medicine Research Center, Biomedicine Institute, Tabriz University of Medical Sciences, Tabriz, Iran.

Received: 17 February 2021 Accepted: 27 April 2021 Published online: 12 May 2021

\section{References}

1. Valant-Vetschera K, Fischer R, Wollenweber E (2003) Exudate flavonoids in species of Artemisia (Asteraceae-Anthemideae): new results and chemosystematic interpretation. Biochem Syst Ecol 31(5):487-498

2. Lee SH, Lee M-Y, Kang H-M, Han DC, Son K-H, Yang DC et al (2003) Antitumor activity of the farnesyl-protein transferase inhibitors arteminolides, isolated from Artemisa. Bioorg Med Chem 11(21):4545-4549

3. Ferreira JF, Luthria DL, Sasaki T, Heyerick A (2010) Flavonoids from Artemisia annua L. as antioxidants and their potential synergism with artemisinin against malaria and cancer. Molecules. 15(5):3135-70

4. Habibi Z, Yousefi M, Mohammadi M, Eftekhar F, Biniyaz T, Rustaiyan A (2010) Chemical composition and antibacterial activity of the volatile oils from Artemisia turcomanica. Chem Nat Compd 46(5):819-821

5. Moscatelli V, Hnatyszyn O, Acevedo C, Megías J, Alcaraz MJ, Ferraro G (2006) Flavonoids from Artemisia copa with anti-inflammatory activity. Planta Med 72(01):72-74

6. Zhou Y, Wang W, Tang L, Yan X, Shi L, Wang Y et al (2009) Lignan and flavonoid glycosides from Urtica laetevirens Maxim. J Nat Med 63(1):100-1

7. Mabry TJ, Markham KR, Thomas MB (1970) Reagents and procedures for the ultraviolet spectral analysis of flavonoids. Springer, The systematic identification of flavonoids, pp 35-40

8. Afshar FH, Delazar A, Nazemiyeh H, Khodaie L, Moghaddam SB (2015) Phenolic Derivatives of Artemisia Spicigera C. Koch Growing in Iran. Iran J Pharm Res 14(4):1241

9. Hartwig UA, Maxwell CA, Joseph CM, Phillips DA (1990) Chrysoeriol and luteolin released from alfalfa seeds induce nod genes in Rhizobium meliloti. Plant Physiol 92(1):116-122
10. Andersen OM, Markham KR (2005) Flavonoids: chemistry, biochemistry and applications. CRC Press, New York

11. Heshmati Afshar F, Asgharian P, Khodaie L, Delazar A, Lotfipour F, Baradaran B. Anti-proliferative and antimicrobial activity of methanolic extract and SPE fractions of Artemisia spicigera (2017). Jundishapur J Nat Pharm Prod 12(2)

12. Tarhriz V, Eyvazi S, Musavi M, Abasi M, Sharifi K, Ghanbarian H et al (2019) Transient induction of C $\mathrm{k}$. in the early stage of differentiation is critical for myogenesis. J Cell Biochem 120(11):18854-18861

13. Tarhriz V, Eyvazi S, Shakeri E, Hejazi MS, Dilmaghani A (2020) Antibacterial and antifungal activity of novel freshwater bacterium Tabrizicola aquatica as a prominent natural antibiotic available in Qurugol Lake. Pharm Sci 26(1):88-92

14. Asgharian P, Afshar FH, Asnaashari S, Lotfipour F, Baradaran B (2017) Evaluation of various biological activities of the aerial parts of Scrophularia frigida growing in Iran. IJPR 16(1):277

15. Mathers C (2008) The global burden of disease: 2004 update. World Health Organization, Berlin

16. Greenlee RT, Murray T, Bolden S, Wingo PA (2000) Cancer statistics, 2000. CA J Clin. 50(1):7-33

17. Safarzadeh E, Delazar A, Kazemi T, Orangi M, Shanehbandi D, Esnaashari S. The cytotoxic and apoptotic effects of Scrophularia atropatana extracts on human breast cancer cells. 2017.

18. Hajdú Z, Hohmann J, Forgo P, Máthé I, Molnár J, Zupkó I (2014) Antiproliferative activity of Artemisia asiatica extract and its constituents on human tumor cell lines. Planta Med 80(18):1692-1697

19. Kawaii S, Tomono Y, Katase E, Ogawa K, Yano M (1999) Antiproliferative activity of flavonoids on several cancer cell lines. Biosci Biotechnol Biochem 63(5):896-899

20. Lim DY, Jeong Y, Tyner AL, Park JH (2007) Induction of cell cycle arrest and apoptosis in HT-29 human colon cancer cells by the dietary compound luteolin. Am J Physiol Gastrointest Liver Physiol. 292(1):G66-G75

21. Lee HS, Cho HJ, Yu R, Lee KW, Chun HS, Park JHY (2014) Mechanisms underlying apoptosis-inducing effects of Kaempferol in HT-29 human colon cancer cells. Int J Mol Sci 15(2):2722-2737

22. Pichette A, Eftekhari A, Georges P, Lavoie S, Mshvildadze V, Legault J (2010) Cytotoxic phenolic compounds in leaf buds of Populus tremuloides. Can J Chem 88(2):104-110

23. Afshar FH, Delazar A, Nazemiyeh H, Nahar L, Moghaddam SB, Mbaebie BO et al (2017) Melilotoside Derivatives from Artemisia splendens (Asteraceae). Records of Natural Products 11(1):43

24. Duong TH, Beniddir MA, Nguyen VK, Aree T, Gallard JF, Mac DH et al (2018) Sulfonic acid-containing flavonoids from the roots of Phyllanthus acidus. J Nat Prod. 81(9):2026-31

25. Ryakhovskaya T, Manadilova A, Sapko O (1985) Flavonoids of Artemisia sublessingiana. Chem Nat Compd 21(3):381-382

26. Galati G, Moridani MY, Chan TS, O'Brien PJ (2001) Peroxidative metabolism of apigenin and naringenin versus luteolin and quercetin: glutathione oxidation and conjugation. Free Radical Biol Med 30(4):370-382

27. Mabry T, Markham KR, Thomas MB (2012) The systematic identification of flavonoids. Springer, Berlin

28. Avula B, Wang Y-H, Smillie TJ, Mabusela W, Vincent L, Weitz F et al (2009) Quantitative determination of flavonoids by column high-performance liquid chromatography with mass spectrometry and ultraviolet absorption detection in Artemisia afra and comparative studies with various species of Artemisia plants. J AOAC Int 92(2):633-644

29. Ahameethunisa AR, Hopper W (2010) Antibacterial activity of Artemisia nilagirica leaf extracts against clinical and phytopathogenic bacteria. BMC Complement Altern Med 10(1):6

30. Naik SK, Mohanty S, Padhi A, Pati R, Sonawane A (2014) Evaluation of antibacterial and cytotoxic activity of Artemisia nilagirica and Murraya koenigii leaf extracts against mycobacteria and macrophages. BMC Complement Altern Med 14(1):87

31. Alzoreky N, Nakahara K (2003) Antibacterial activity of extracts from some edible plants commonly consumed in Asia. Int J Food Microbiol 80(3):223-230

32. Shan B, Cai Y-Z, Brooks JD, Corke H (2007) The in vitro antibacterial activity of dietary spice and medicinal herb extracts. Int J Food Microbiol 117(1):112-119 
33. Chen C-P, Lin C-C, Tsuneo N (1989) Screening of Taiwanese crude drugs for antibacterial activity against Streptococcus mutans. J Ethnopharmacol 27(3):285-295

34. Deng S, Deng Z, Fan Y, Peng Y, Li J, Xiong D et al (2009) Isolation and purification of three flavonoid glycosides from the leaves of Nelumbo nucifera (Lotus) by high-speed counter-current chromatography. J Chromatogr B 877(24):2487-2492

35. Wei Y, Xie Q, Fisher D, Sutherland IA (2011) Separation of patuletin-3-Oglucoside, astragalin, quercetin, kaempferol and isorhamnetin from Flaveria bidentis (L.) Kuntze by elution-pump-out high-performance counter-current chromatography. J Chromatogr A. 1218(36):6206-11

36. Chumbalov T, Fadeeva O (1969) Flavonoids of Artemisia transiliensis. Chem Nat Compounds. 5(5):364

37. Lee YS, Lee S, Lee HS, Kim B-K, Ohuchi K, Shin KH (2005) Inhibitory effects of isorhamnetin-3-O- $\beta$-D-glucoside from Salicornia herbacea on rat lens aldose reductase and sorbitol accumulation in streptozotocin-induced diabetic rat tissues. Biol Pharm Bull 28(5):916-918
38. Wang Y, Yin J, Qiao Y, Zhang H, Lu X. Studies on antioxidant activity and chemical constituents of Artemisia halodendron. 亚洲传统医药. 2007;2(1):30-3

39. Dehaghani ZA, Asghari G, Dinani MS (2017) Isolation and Identification of Nicotiflorin and Narcissin from the Aerial Parts of Peucedanum aucheri Boiss. J Agric Sci Technol A. 54:45

40. Ruakhovskaya T, Manadilova A, Sapco O. The flavonoids of Artemisia sublessingiana. Akademiya nauk uzbekskol SSR UL kuibysheva 15, Tashkent, Uzbekistan; 1985. p. 407.

41. Agrawal PK, Rastogi R (1981) C-13 NMR-spectroscopy of flavonoids. Heterocycles 16(12):2181-2236

\section{Publisher's Note}

Springer Nature remains neutral with regard to jurisdictional claims in published maps and institutional affiliations.
Ready to submit your research? Choose BMC and benefit from:

- fast, convenient online submission

- thorough peer review by experienced researchers in your field

- rapid publication on acceptance

- support for research data, including large and complex data types

- gold Open Access which fosters wider collaboration and increased citations

- maximum visibility for your research: over $100 \mathrm{M}$ website views per year

At BMC, research is always in progress.

Learn more biomedcentral.com/submissions 